\title{
SEXUAL CALLING BEHAVIOR IN HIGHLY PRIMITIVE ANTS*
}

\author{
BY CARYL P. HASKINS \\ Haskins Laboratories, New Haven. Connecticut 06510
}

In recent years an interesting mating pattern has been discovered in a number of socially parasitic and dulotic Myrmicine ants, including the related genera Leptothorax, Doronomyrmex, and Harpagoxenus, and in the guest ant Formicoxenus nitidulus (Buschinger, 1968, 1971a, 1971 b, 1974; 1975). Typically the alate or ergatoid young female leaves the parent colony, crawls to a prominent position, and settles there motionless for a long period sometimes amounting to hours - with gaster raised, legs extended, and sting extruded. Sooner or later males assemble about the "calling" female, and mating takes place. Buschinger, who first observed it in these genera, has described the pattern in detail for the slave-making Harpagoxenus sublaevis (1968), and in the permanently socially parasitic Doronomyrmex pacis, Leptothorax kutteri, and $L$. goesswaldi (1975). He also observed the pattern in fine detail in populations of $F$. nitidulus (1975) maintained in the laboratory as guests of Leptothorax acervorum, and found it generally similar to the others, though differing in detail in ways to which we will later allude. Buschinger was able to demonstrate that in all these forms a sex-attractant pheromone was released from the poison gland, as Hölldobler (1971) had been the first to demonstrate in the Myrmicine ant Xenomyrmex floridanus.

Recently Möglich, Maschwitz, and Hölldobler (1974), in a particularly provocative study, have presented the results of detailed analyses of "tandem-calling" behavior in the independently-living Leptothorax acervorum, L. muscorum, and L. nylanderi, a pattern by which workers of these independently-living species recruit sisters to newly discovered food sources, one recruiter guiding only one follower to the source at a time. A component of the initial behavior of the recruiting worker is described as essentially identical with the "calling" behavior in Harpagoxenus females, and the authors call attention to the interesting hypothesis posited earlier by Hölldobler (1971) that, in at least some Myrmicine ants, sex

*Manuscript received by the editor May 15, 1979. 
attractants and recruitment pheromones may have had a common evolutionary origin.

In view of these findings and this challenging suggestion, it becomes unusually interesting to query how early in Formicid evolution the "calling" behavior may have originated. For this reason we are led to put on record some observations of a similar behavior pattern made several years ago in the highly archaic Ponerine genus Amblyopone, and also to elaborate some further observations of the same kind in the genus Rhytidoponera, a part but not all of which has been noted priviously (Haskins and Whelden, 1965), but without particular reference to this context.

\section{The Genus Amblyopone}

The Ponerine genus Amblyopone includes a rather large group of species widely distributed over the world. In anatomy, colony structure, and behavior patterns they must certainly rank among the most archaic of surviving ants, rivalling or even exceeding in their primitiveness, the very different but also immensely archaic genus Myrmecia, as Wilson (1975) has recently emphasized. It was thus of interest to observe what clearly seems to be "calling" behavior in virgin females of two species - the North American A. pallipes and the Australian $A$. australis, both widely distributed and fairly common forms in their respective habitats.

Amblyopone pallipes: From 1924 to 1927 an extensive and continuous series of observations was undertaken in the laboratory and field in an attempt to elucidate the nuptial flight and colonyfounding behavior patterns in A. pallipes. This species appears to be ordinarily completely hypogeaic in habit, foraging entirely underground to satisfy its wholly entomophagous and highly specialized dietary requirements, normally if not invariably confined to a very limited range of Myriopoda. During late summer in the regions of New York State and Massachusetts where the work was done the galleries and chambers of the colonies are concentrated near the surface of the soil, commonly under logs or stones, and are characteristically crammed with cocoons of both sexes and castes. The alate females and males eclose there, and shortly escape aboveground, singly or in small groups. The males, fully pigmented, fly off at once. The females, still of the red callow coloration, climb prominent objects in the vicinity. They may or may not make short 
flights from these vantage points before coming to rest. They then adopt a posture closely similar to that described for the Leptothoracine ants, resting motionless with legs and antennae extended, gaster arched, and sting protruded or slowly alternately exserted and withdrawn. Characteristically, the arched gaster is rubbed by the tibia of one or the other of the third pair of legs. At the height of the flight season in the localities investigated (typically shady woodlands) numbers of low-flying males soon appeared, landed on vegetation near the female in a high state of arousal, and after some running, one quickly copulated. Often, as in cases described by Buschinger, males attempted to mount one another. Following copulation, females characteristically exhibited reversed phototropism and geotropism and promptly retired underground. This behavior was observed repeatedly both with alate females naturally emerging from wild colonies, and with females reared in the laboratory and subsequently released in appropriate localities. Unfortunately, no determinations were made of the source of the pheromone. The prominence of the sting movements suggest that the source may well, as in Leptothorax, have been the sting gland, but the Dufours gland has not been experimentally ruled out at this time, as the source.

Amblyopone australis: A. australis, widely distributed in Australia and in the Pacific Islands as far as New Zealand, is larger and "bolder" in demeanor and habitus than $A$. pallipes, but in general resembles it quite closely. It is, however, partly epigeaic and a much more generalized Arthropod feeder. In this species colony foundation by isolated dealated females has been demonstrated (Haskins and Haskins, 1951). During this period the foundresses forage episodically from their frequently-opened cells in the general pattern of colony-founding females of Myrmecia. In the course of work designed to delineate the details of this pattern, alate young females eclosing from pupae collected in the wild were released under observation in appropriate locations. Some of these released females flew briefly, but all soon adopted the "calling" pattern, although, on the occasions of the experiments, no males appeared.

\section{The Genus Rhytidoponera}

Rhytidoponera is a generalized Ectatommine genus widely distributed in Australia (its apparent headquarters), but extending to 
TABLE I

\begin{tabular}{|c|c|c|c|}
\hline Colony no. & $\begin{array}{c}\text { Date of } \\
\text { Observation } \\
\end{array}$ & $\begin{array}{c}\text { Time of } \\
\text { Observation } \\
\end{array}$ & $\begin{array}{c}\text { Number of } \\
\text { Workers Involved } \\
\end{array}$ \\
\hline 1 & $4 / 29 / 68$ & & 1 \\
\hline \multirow[t]{25}{*}{2} & $4 / 8 / 75$ & 7:45 a.m. & 15 \\
\hline & & 8:45 a.m. & 11 \\
\hline & & 8:55 a.m. & 2 \\
\hline & $4 / 12 / 75$ & 7:00 a.m. & 11 \\
\hline & $4 / 16 / 75$ & 5:30 a.m. & 10 \\
\hline & $4 / 21 / 75$ & $7: 25$ a.m. & 6 \\
\hline & $4 / 29 / 75$ & 7:05 a.m. & 2 \\
\hline & $4 / 30 / 75$ & 7:05 a.m. & 1 \\
\hline & $5 / 2 / 75$ & 7:00 a.m. & 2 \\
\hline & $5 / 6 / 75$ & 7:10 a.m. & 6 \\
\hline & $5 / 7 / 75$ & 7:10 a.m. & 2 \\
\hline & $5 / 8 / 75$ & 6:30 a.m. & 3 \\
\hline & $5 / 13 / 75$ & 7:40 a.m. & 2 \\
\hline & $5 / 14 / 75$ & 5:50 a.m. & 5 \\
\hline & $5 / 15 / 75$ & 6:55 a.m. & 9 \\
\hline & $5 / 16 / 75$ & 7:00 a.m. & 2 \\
\hline & $5 / 22 / 75$ & 8:00 a.m. & 2 \\
\hline & $6 / 3 / 75$ & $6: 45$ a.m. & 2 \\
\hline & $6 / 7 / 75$ & 6:45 a.m. & 2 \\
\hline & $7 / 22 / 75$ & 6:30 a.m. & 9 \\
\hline & $10 / 1 / 75$ & 7:50 a.m. & 1 \\
\hline & $1 / 17 / 76$ & 7:00 a.m. & 6 \\
\hline & $3 / 22 / 76$ & 7:25 a.m. & 3 \\
\hline & $3 / 23 / 76$ & 5:55 a.m. & 2 \\
\hline & $3 / 25 / 76$ & 6:25 a.m. & 3 \\
\hline Colony no. & $\begin{array}{c}\text { Date of } \\
\text { Observation } \\
\end{array}$ & $\begin{array}{c}\text { Time of } \\
\text { Observation } \\
\end{array}$ & $\begin{array}{c}\text { Number of } \\
\text { Workers Involved } \\
\end{array}$ \\
\hline 3 & $5 / 22 / 75$ & $8: 10$ a.m. & 1 \\
\hline (Male flights & $4 / 16 / 75$ & $5: 30$ a.m. & \\
\hline $\begin{array}{l}\text { in this colony } \\
\text { only) }\end{array}$ & $5 / 14 / 75$ & 5:50 a.m. & \\
\hline
\end{tabular}


TABLE 1 (continued)

\begin{tabular}{|c|c|c|c|}
\hline Colony no. & $\begin{array}{c}\text { Date of } \\
\text { Observation } \\
\end{array}$ & $\begin{array}{c}\text { Time of } \\
\text { Observation } \\
\end{array}$ & $\begin{array}{c}\text { Number of } \\
\text { Workers Involved } \\
\end{array}$ \\
\hline \multirow[t]{12}{*}{4} & $4 / 8 / 75$ & 7:45 a.m. & 3 \\
\hline & & 8:45 a.m. & 2 \\
\hline & & 8:55 a.m. & 3 \\
\hline & $4 / 12 / 75$ & 7:25 a.m. & 3 \\
\hline & $4 / 29 / 75$ & 7:05 a.m. & 1 \\
\hline & $4 / 30 / 75$ & 7:05 a.m. & 3 \\
\hline & $5 / 6 / 75$ & $7: 10$ a.m. & 4 \\
\hline & $5 / 8 / 75$ & 6:35 a.m. & 2 \\
\hline & $5 / 13 / 75$ & 7:40 a.m. & 2 \\
\hline & $5 / 14 / 75$ & 5:50 a.m. & 1 \\
\hline & $5 / 15 / 75$ & 6:40 a.m. & 5 \\
\hline & $6 / 3 / 75$ & 6:45 a.m. & 3 \\
\hline
\end{tabular}

New Guinea, to neighboring regions of Melanesia, and to Timor, the Moluccas, the Solomon Islands, and the Philippines (Browii, 1958; Wilson, 1958; 1959). The genus is a large one, and ranges from tropical rain-forest environments at one latitudinal extreme of its range to temperate and relatively wet habitats in southern Victoria and Tasmania and the extreme Australian southwest, while one group within the genus has invaded highly xerophytic environments in the Australian inland. A large number of species are particularly interesting in that normal alate females are either absent or rare and apparently do not take a normal part in colony functions. Instead a proportion of workers, externally morphologically indistinguishable from their fellows, possess functional spermathecae, are fertilized by the active, low-flying males, and serve as multiple worker-producing reproductives in the colony (Whelden, 1957; 1960; Haskins and Whelden, 1965).

Rhytidoponera is a fairly dominant genus where it occurs, and, as Brown (1958) has pointed out, its more abundant members appear to occupy in Australia the ecological niche of such relatively primitive general-feeding Myrmicines as the genus Myrmica in palearctic and nearctic environments. Indeed, it has been suggested that the primitive Ectatommines may be fairly close to the ancestral stirp of the Myrmicinae.

The commonest and best-known member of the genus Rhytidoponera is $R$. metallica, the Australian "greenhead" ant. It is fairly 
ubiquitous in eastern Australia, even commonly invading parks and gardens. It is readily obtainable, easy of culture, and in general a nearly ideal laboratory animal for the study of behavioral patterns in that section of the genus in which normal alate females are usually lacking.

In the course of a ten-year study of this species in the laboratory and the field, particular attention was paid to the mode of mating of the fertilized workers, and of the founding of new colonies. In the course of this investigation, numerous observations have been made of worker behavior closely resembling the "calling" pattern in Leptothorax. The earliest of these observations were recorded several years ago (Haskins and Whelden, 1965) but as they have been considerably expanded since, and as they seem to "fit" so accurately the pattern described for Leptothorax and its congeners, it has seemed appropriate to expand the record.

In $R$. metallica males are produced irregularly throughout the year, both in the laboratory and in the field. They are characteristically low-flying, and W. L. Brown, Jr. some years ago observed them coursing closely over the ground, and entering the nests of other colonies (unpublished observations).

In laboratory colonies, as earlier described (Haskins and Whelden, 1965) groups of workers were observed in September, 1952 , to emerge from the artificial nests and rest quietly grouped near their entrances, with head and thorax closely appressed to the substrate and gaster raised and arched. At the same time, the sting was characteristically exserted. This immobile "pose" was usually main-tained only briefly, but in the longest interval recorded, for over twelve minutes. It was commonly interrupted eventually by other foraging or recently "calling" workers nearby. During this process, copulations might occur with recently emerged males, although there was no clearly exhibited preference of males for "calling" workers over those that were wandering or foraging normally. ${ }^{1}$

Since these observations were published, this pattern has been observed repeatedly in further colonies of $R$. metallica housed in laboratory nests. The sets of observations shown below are typical. They involved three colonies in all, originally collected at Nam-

\footnotetext{
'See Hölldobler, B. and C. P. Haskins (Science 195, 793-794) for illustrations of this behavior.
} 
bours, Northern Queensland, in December of 1963, and maintained under constant conditions in the laboratory since that time.

Several details of interest emerged from this range of observations. The first was the virtually seasonally-independent nature of the events. In 1952 "calling" workers were seen in September and October, in 1953 in July and November, in 1975 in April, May, June, July, and October, in 1976 in January and March. Thus every month was represented except February, August, and December. This is particularly noteworthy since the observations of 1952 and 1953 were made on colonies from a population taken near Sutherland, N.S.W. in essentially a temperate location, while those for 1975-76 were derived from a population in the vicinity of Nambours, Queensland, many miles to the north and in essentially a tropical rain forest area.

Flights of males, as noted both by Brown (1958) and ourselves (1965), are likewise highly non-specific with respect to season. Worker "calling" and male flights both appear to take place predominantly during early to mid-morning hours. It is of interest, also, that the presence of males in the nest, much less their emergence, is not a prerequisite for worker "calling". During the observations of "calling" made in January, 1957 and May 1975 males were present in the nests, and in at least one case there was simultaneous male emergence. However, worker "calling" took place in the absence of male flights in October, 1952 and July 1953 (involving the same colonies in which males were present during "calling" in 1957) and in all of the 34 instances recorded for Colonies 1 and 3 . In both those colonies males had long been absent, and examination of samples of pupae present in Colony \#1 (3) made during the height of the "calling" period in that small community revealed only workers to be present in the brood.

The length of time of the "calling" behavior of workers of $R$. metallica is typically brief, averaging 1-2 minutes (although one record period of more than 12 minutes has been noted). Usually, however, workers moved about after a short period, commonly resuming the behavior at another location. In this respect, the pattern resembled that observed by Buschinger for Formicoxenus nitidulus.

It seems probable that this behavior in $R$. metallica (observed also in three other species of the genus: $R$. tasmaniensis; $R$. inornata, and $R$. violacea) does indeed correspond quite closely with 
the typical "calling" pattern in Leptothorax and the related Myrmicine genera where it has been observed. As in those cases, the sting is clearly exserted during the "calling" process, but Hölldobler (Hölldobler and Haskins, 1977) has clearly demonstrated that here the newly-described tergal gland, strongly developed in Rhytidoponera is an important, if not the sole, source of the pheromone. ${ }^{2}$

With Rhytidoponera, as with Amblyopone, the behavior is evidently only of sexual significance. No evidence of any workerworker recruiting has been obtained for either genus.

It seems of real interest that the "calling" behavior seems to be well established, entirely in a sexual context, at so primitive a grade of Formicid evolution. It is particularly interesting that it should be so clearly demonstrated within the Ectatommini, a division of the Ponerinae which, on morphological grounds, is thought to be fairly close to the main evolutionary stem leading from the Ponerinae to the Myrmicinae. Finally, the nature of the colonies and the nuptial flights of both Amblyopone and Rhytidoponera emphasizes a reflection of Buschinger, who has suggested (1975) that there may well be a correlation between the "use" of male mandibular-glandderived sex pheromones in the mediation of highly coordinated massive mating swarms and of female sex pheromones, derived from sting or Dufours glands, in smaller, poorly coordinated "straggling" colony flights. The former are characteristic of ant species forming large closely-knit communities, the latter of those existing in smaller, more diffuse, less highly integrated communities of species which are often more rare. Though none of the species considered here is especially rare, all do form typically scattered, rather feebly integrated communities having inconspicuous and essentially uncoordinated nuptial flights.

\section{Literature Cited}

BUSCHINGER, A.

1968. "Locksterzeln" begattungsbereiter ergatoider Weiber von Harpagoxenus sublaevis NYL. (Hymenoptera Formicidae). Experientia 24: 297.

1971a. "Locksterzeln" und Kopula der sozialparasitischen Amiese Leptothorax kutteri Buschiner (Hym., Form.). Zool. Anz. 186: 242-248.

$1971 \mathrm{~b}$. Weitere Untersuchen zum Begattungsverhalten sozialparasitischer Ameisen (Harpagoxenus sublaevis Nyl. und Doronomyrmex pacis Kutter, Hym., Formicidae). Zool. Anz. 187: 184-198.

\footnotetext{
${ }^{2}$ An extensive paper by B. Hölldobler and $\mathrm{H}$. Engel on tergal and sternal glands in ants is included in this issue of Psyche.
} 
1974. Zur Biologie der sozialparasitischen Ameise Leptothorax goesswaldi Kutter (Hym., Formicidae). Insectes Sociaux 21: 133-143.

1975. Sexual pheromones in ants. International Union for Study of Social Insects, Proc. of Symposium on Pheromones and Defensive Secretions in Social Insects, September, 1975, Dijon, pp. 225-233.

BROWN, W.L., JR.

1958. Contributions toward a reclassification of the Formicidae: Il. Tribe Ectatommini (Hymenoptera). Bull. Mus. Comp. Zool. Harvard 118(5): 175-362.

1954. Systematic and other notes on some of the smaller species of the ant genus Rhytidoponera. Breviora: Mus. Comp. Zool. Harvard 33: 1-11.

HaSkins, C.P. AND E.F. HASKINS

1951. Note on the method of colony foundation of the ponerine ant Amblyopone australis. Amer. Midland Naturalist 45(2): 432-445.

HASKINS, C.P. AND R.M. WheldEN

1965. Queenlessness, worker sibship, and colony versus population structure in the formicid genus Rhytidoponera. Psyche 72: 87-111.

HöLLDOBLER, B.

1971. Sex pheromone in the ant Xenomyrmex floridanus. J. Insect Physiology 17: $1497-1499$

HÖLlDOBler, B. AND C.P. HASKINS

1977. Sexual calling in a primitive ant. Science 195: 793-794.

Moglich, M., U. Maschwitz AND B. HölldobleR

1974. Tandem calling: a new kind of signal in ant communication. Science 186: 1046-1047.

WHELDEN, R.M.

1957. Anatomy of Rhytidoponera convexa. Ann. Ent. Soc. Am. 50: 271-282.

1960. Anatomy of Rhytidoponera metallica. Ann. Ent. Soc. Am. 53: 793-808. WILSON, E.O.

1958. Studies on the ant fauna of Melanesia III. Rhytidoponera in western Melanesia and the Moluccas. Bull. Mus. Comp. Zool. Harvard 119(4): 303-320.

1959. Adaptive shift and dispersal in a tropical ant fauna. Evolution 13(1): 122-144.

1975. Sociobiology. Belknap Press of the Harvard University Press. Cambridge, Massachusetts 02138. 

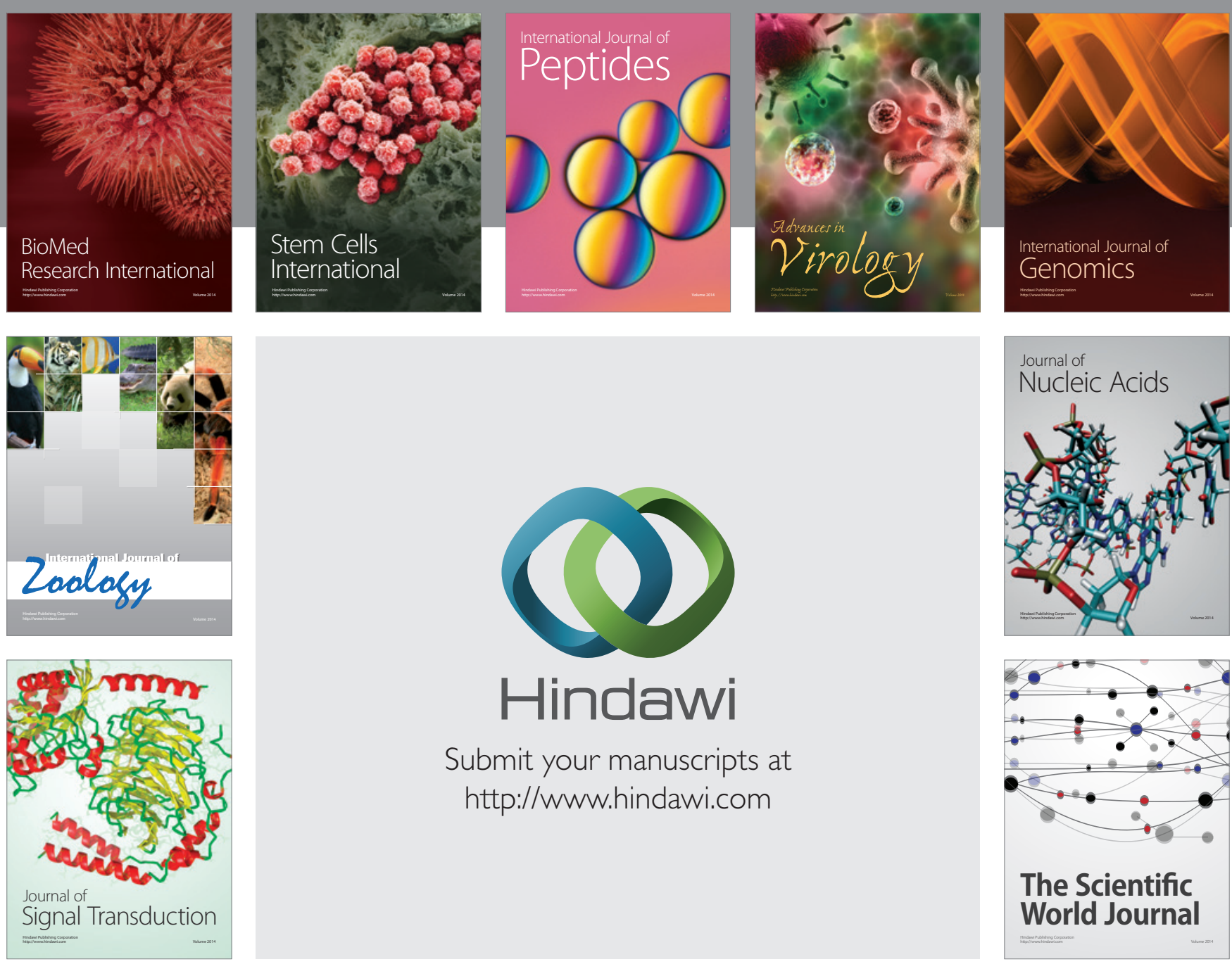

Submit your manuscripts at

http://www.hindawi.com
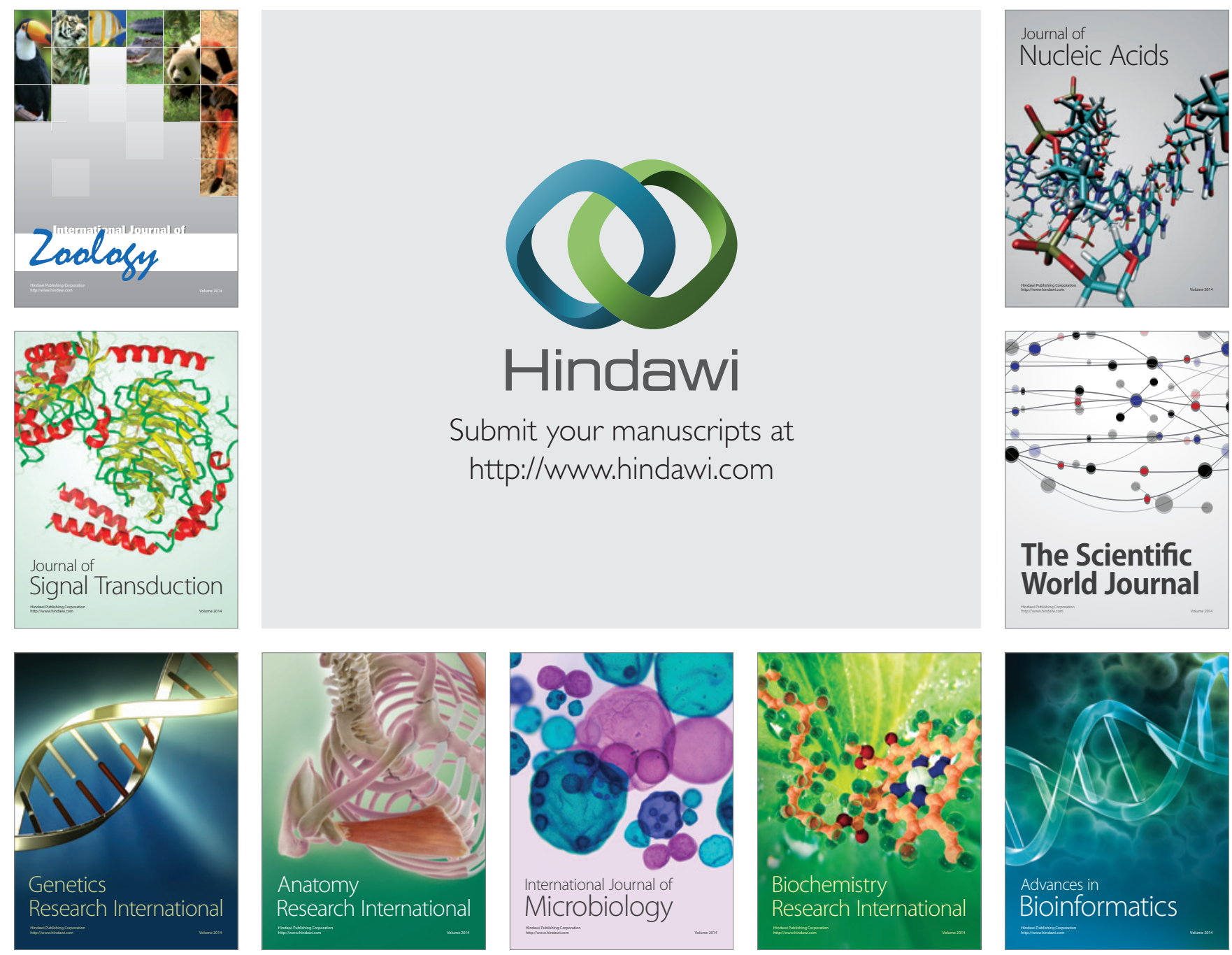

The Scientific World Journal
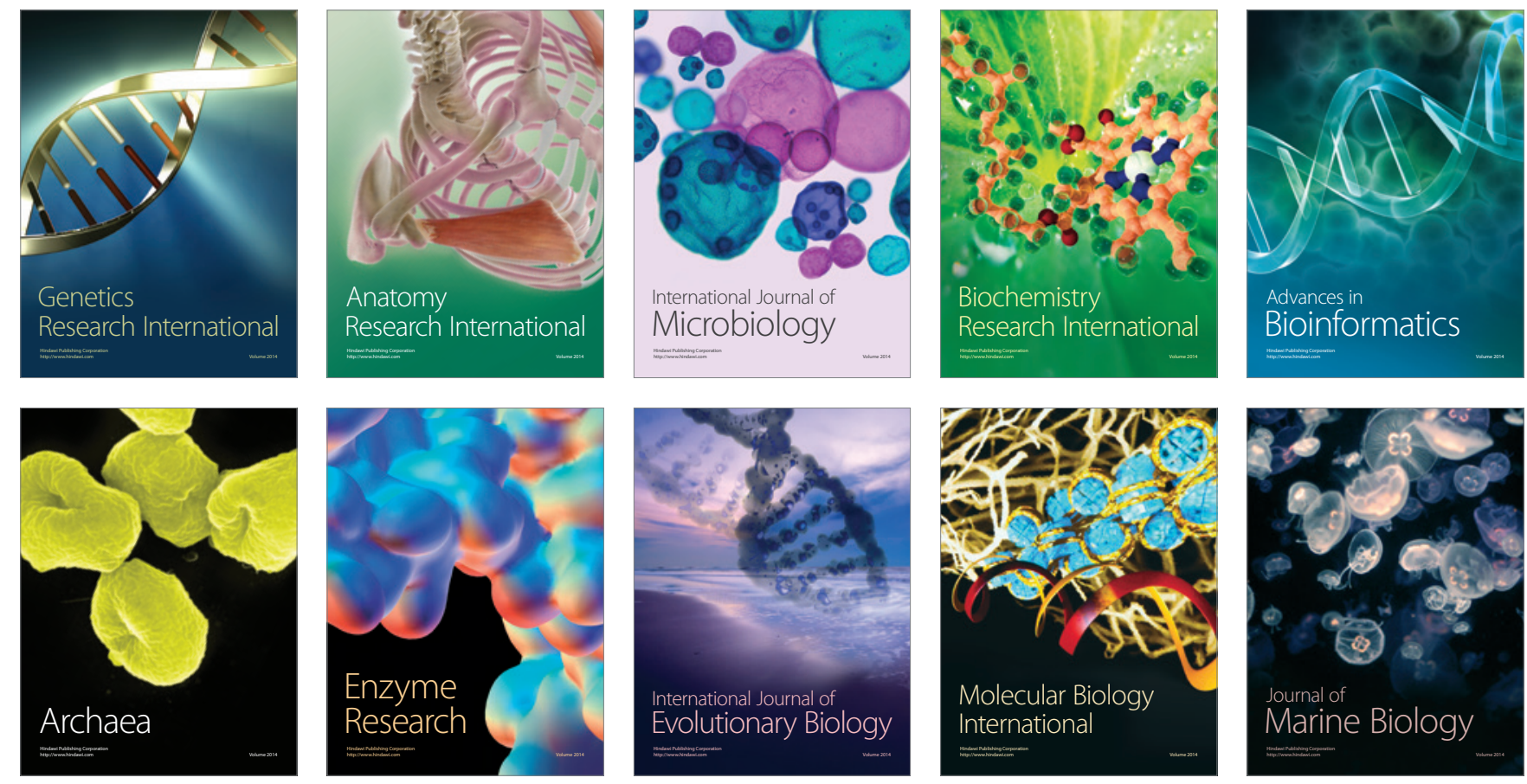